\title{
Sustainability Planning and Benchmarking of Post Concession Performance of Nigerian Seaports: The Case of Onne Seaport
}

\author{
Theophilus Chinyerem NWOKEDI ${ }^{1}$, Gladys Chineze EMENIKE ${ }^{2}$ \\ ${ }^{1}$ Department of Maritime Management Technology, Federal University of Technology, Nigeria \\ ${ }^{2}$ Center for Transport and Logistics Studies, University of Port-Harcourt, Nigeria \\ nwokeditc@gmail.com; ORCID ID: https://orcid.org/0000-0002-9441-7311 \\ chiemenike@gmail.com; ORCID ID: https://orcid.org/0000-0002-8570-8627
}

\begin{abstract}
The study appraised the sustainability of the improvement in post concession cargo throughput, revenue, ship traffic statistics and ship traffic volume performance of Onne seaport and developed benchmarks and planning models for sustainability of Onne seaport performance. Time series data of 10 years was gathered from the Nigerian ports authority on post concession cargo throughput, port revenue, ship traffic statistic and ship traffic volume performances of the seaport. The Arithmetic progression and series mathematical tool were used to analyze the data. It was found that; the post concession performance benchmark for each performance parameter of cargo throughput, port revenue, ship traffic volume and ship traffic statistics are $C_{1}=2,554,795$ metric tons, $R_{1}=103.76$ Million USD, $S_{1}=256,831,040$ NRT, and $V_{1}=443$ vessels respectively. The conditions for sustainability of the post concession cargo throughput, port revenue, ship traffic volume and ship traffic statistics performance of the port are: $C_{1}+(n-1) d \geq 2,554,795$ metric tons, $R_{1}+(n-1) d \geq 103.76$ Million $U S D, S_{1}+(n-1) d \geq 256,831,040$ Net Registered Tonnage and $V_{1}+(n-1) d \geq 443$ respectively. Recommendations were proffered on the basis of the research findings.
\end{abstract}

Keywords: Sustainability-planning, Benchmarking, Post-concession, Seaport, Performance.

\section{Nijerya Limanlarının İmtiyaz Sonrası Performansının Sürdürülebilirlik Planlaması ve Karşılaştırması: Onne Limanı Örneği}

Öz

Çalısmada; Onne Limanı'nın imtiyaz sonrası yük hacmi, geliri, gemi trafik istatistiği ve gemi trafik hacmi performanslarındakiiyileșmeninsürdürülebilirliğideğerlendirilmişveOnneLimanıperformansınınsürdürülebilirlĭgi için karşılaştırmalar ve planlama modelleri geliştirilmiștir. Nijerya Limanlar Otoritesi'nden limanın imtiyaz sonrası yükhacmi, liman geliri, gemi trafik istatistiği ve gemi trafik hacmi performanslart ile ilgili 10yllıkzaman serisi verileri toplanmıștır. Verilerin analizinde aritmetik dizi ve seriler kullanılmıștır. Yük hacmi, liman geliri, gemi trafik hacmi ve gemi trafik istatistiği ile ilgili her bir performans parametresi için imtiyaz sonrası performans ölçütü sırasıyla; $C_{1}$ $=2,554,795$ metrik ton, $R_{1}=103.76$ milyon dolar, $S_{1}=256,831,040$ NRT ve $V_{1}=443$ gemi bulunmuştur. Limanın imtiyaz sonrası yük hacmi, geliri, gemi trafik hacmi ve gemi trafik istatistiği performanslarının sürdürülebilirliğine yönelik koşulları sirasiyla; $C_{1}+(n-1) d \geq 2,554,795$ metrik ton, $R_{1}+(n-1) d \geq 103.76$ milyon dolar, $S_{1}+(n-1) d \geq$ 256,831,040 NRT ve $V_{1}+(n-1) d \geq 443$ gemidir. Araștırma bulgularına dayanarak tavsiyeler sunulmuştur.

Anahtar Kelimeler: Sürdürülebilirlik planlaması, Karşılaştırma, İmtiyaz sonrası, Liman, Performans.

To cite this article: Nwokedi, T. C. and Emenike, G. C. (2018). Sustainability Planning and Benchmarking of Post Concession Performance of Nigerian Seaports: The Case of Onne Seaport. Journal of ETA Maritime Science, 6(3), 181-197.

To link to this article: https://dx.doi.org/10.5505/jems.2018.95914 


\section{Introduction}

Reference [1] defines sustainability as a concept which encompasses the ability of a system or process to meet the objectives and needs of today without compromising its ability to meet the needs and/ or objectives of the future. Thus, the concept of sustainability requires that the system meets the demand of today, with capacity to certainly meet the demand of future generations. Maritime transport and seaports have basic functions of trade facilitation, employment generation, and revenue objectives which all gears towards economic growth and development of coastal states. Thus, when a seaport system and /or maritime transport system achieves these basic objectives, we may regard such seaport or maritime transport system as productive. The ability to say with certainty that a seaport is productive with regards to the objectives of trade facilitation, employment and revenue generation etc. depends on the level of achievement of productivity/performance targets, which must be quantified prior to performance assessment. Seaport performance appraisal must, therefore, quantify the minimum target and benchmark as the basis for performance assessment decisions. Appraisal of performance sustainability can equally be based on this minimum performance benchmark. To sustain this acceptable level of performance target generationally and causing it to diverge from the basic benchmark/target into higher performance levels without diminishing to lower performance levels than the target benchmark, one may assert with accuracy that such a seaport or maritime transport system is a sustainable system; since it has the basic ability to fulfill present performance demand while guaranteeing future demand requirements. The implication of this is that a quantified without basis (acceptable performance or productivity benchmark or target), it is impossible to determine whether the performance of a seaport for instance is sustained and /or is sustainable within a reference period; provided that there is the availability of input resources in adequate and/ or right level [1]. Sustainability of performance and/or productivity can therefore only be successfully appraised with reference to a target benchmark over any given period. Just as performance can be appraised by reference to a given benchmark, so may input resources with which productivity was achieved and sustained be assessed by reference to a basic input resource benchmark.

[2] notes that in order to improve the productivity and or Performance of Nigerian seaports, the Federal Government of Nigeria embarked on port reform initiatives to reverse the continuously declining and poor performance of the Nigerian ports witnessed in the preconcession era between 1956 and 2004.

A study report by [3] concluded that the administra-tion of the Nigerian ports between 1956 when the Nigerian Ports Authority (NPA) was created by the ports Act as the public administrator of ports to 2002 when the Haskoning study was concluded and winds of port reforms began to blow in Nigeria; was characterized by an unusually high degree of centralization, with the NPA working as a public regulator of ports and port service provider. Reference [3] notes that although the sector was supposed to be controlled by the state-owned Nigerian Ports Authority (NPA), approval by either the President or the Minister of Trans $\urcorner$ port was needed for almost all major decisions. Following the aforementioned, a major decision that affects productivity, policy, and operations in the seaport sector was slowed almost to a standstill such that the performance of the ports with regards to key port productivity indices was poor. Furthermore, NPA was in charge of both regulation of port operations and the day- 
to-day operational decisions and service provision. Because it had the authority to set its own tariffs, NPA was inclined to raise its prices to deal with internal budget deficits, instead of working to improve efficiency and productivity [3, 2]. By the end of the 1990s, repeated tariff increases, along with unchecked inefficiencies and poor governance, had made Nigerian ports among the slowest, least productive and most expensive, in the world such that even Nigerian port users and merchants reroute Nigerian destined cargoes to the neighboring ports of Cotonuo in Benin Republic from where such cargoes were smuggled into the Nigeria markets by land routes $[4,5,2]$.

The Haskoning study recommended the adoption of the government's port management model referred to as "landlord" approach, whereby the NPA (public sector) is responsible for port planning and regulatory tasks as it relates to safety, security and environment, while also maintaining ownership of port-related land and basic infrastructure. The private sector in the landlord model would be responsible for marine and terminal operations, construction, purchase, and ownership of superstructure and equipment. With the recommendation of the Haskoning study, the Nigerian Government began the process of reforming and privatizing the port terminals in the year 2004 and by 2006, the majority of the seaports were privatized by the concession of the port terminals to private terminal operators [6] [7]. Port concession, therefore, is Nigeria's response to the imperatives of reforming and modernizing the port sector in order to increase port productivity and performance and reduce the cost of services to port users. Concession, which transfers port operational obligations to private sectors while retaining public ownership of port infrastructure, was preferred over all other options and it is expected that with concession, performance of the ports with regards to key port performance indicators such as cargo throughput performance, ship traffic volume/ship traffic performance, port revenue as well as such variables as ship turnaround time, cargo dwell time and berth occupancy which affects productivity will improve and end the pre-concession problems and challenges which impinged port performance in that era.

The concession of the Federal Ocean Terminal (FOT) and the Federal Lighter Terminal (FLT) which constitute the Onne seaport concluded in the year 2006. Table 1 below is a summary of post concession terminal operators in Onne port complex showing the available number of berth and port infrastructure on which productivity depends.

Table 1. Terminal Operator in Onne Port and Lease Agreement

\begin{tabular}{|l|l|l|l|l|}
\hline Company name & Terminal & Berths & $\begin{array}{l}\text { Lease terms } \\
(\text { years })\end{array}$ & Handover date \\
\hline Intels Nigeria Ltd & FOT A & $1-6$ & 25 & $21^{\text {st } J \text { Jue } 2006}$ \\
\hline Brawal Oil Services Ltd & FLT A & 1 & 25 & $21^{\text {st }}$ June 2006 \\
\hline Intels Nigeria Ltd & FLT A & $2,3,4$ & 25 & $21^{\text {st } J u n e ~ 2006 ~}$ \\
\hline Atlas Cement Co. Ltd & Jetty FOT A & Jetty & 25 & $21^{\text {st } J u n e ~ 2006 ~}$ \\
\hline $\begin{array}{l}\text { West African Container } \\
\text { Terminal (WACT) }\end{array}$ & FOT B & $7-8$ & 25 & 2007 \\
\hline
\end{tabular}

Source: NPA Bran Manual, 2006 
Table 2. Berth Characteristics of Onne Port

\begin{tabular}{|c|c|c|c|c|}
\hline \multicolumn{2}{|l|}{ Berths } & Quay Length (m) & Draught (m) & Terminal Operator \\
\hline \multicolumn{5}{|c|}{ Federal Lighter Terminal (FLT) } \\
\hline A & 1 & 340 & 7.5 & Brawal \\
\hline \multirow[t]{3}{*}{ B } & 2 & 930 & 8.5 & Intels \\
\hline & 3 & 376 & 10.0 & $”$ \\
\hline & 4 & 376 & 10.0 & 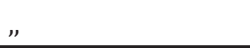 \\
\hline \multicolumn{5}{|c|}{ Federal Ocean Terminal (FOT) } \\
\hline \multirow[t]{6}{*}{ A } & 1 & 250 & 10.0 & Intels \\
\hline & 2 & 250 & 10.0 & $”$ \\
\hline & 3 & 250 & 10.0 & , \\
\hline & 4 & 250 & 12 & Intels \\
\hline & 5 & 250 & 12 & $”$ \\
\hline & 6 & 320 & 12 & ” \\
\hline \multirow[t]{5}{*}{ B } & 7 & 285 & 12 & WACT \\
\hline & 8 & 285 & 12 & WACT \\
\hline & 9 & 250 & 12 & Intels \\
\hline & 10 & 250 & 12 & " \\
\hline & 11 & 250 & 12 & " \\
\hline
\end{tabular}

Source: NPA bulletin

The table above, which indicates the berth characteristics of Onne port, the quay size, draught levels, and the number of berths, is indicative of the level of investment in port infrastructure and input resources upon which port productivity depends. The expectation is that to sustain the present level of Onne port performance or surpass it, the present level of investment in port infrastructure must be continuously maintained and/ or improved upon. That is a key condition necessary to ensure the sustainability of port productivity as a decline in present level of investment in port infrastructure as evidenced in the table by allowing its decay may not at the long run guarantee sustainable port and maritime transport system.

As aforementioned, the concession exercise was aimed to correct the inadequacies of the pre-concession era and put the seaport facility on the roadmap of high performance and productivity. Many studies have been carried out in the past to analyze and/or compare the post and pre concession performance of the seaports. For example, the works of references [8, 9] both found that the post concession performance of Onne port complex with regards to performance indicators as cargo throughput, ship traffic volume, port revenue has improved tremendously, showing significant differences from the pre-concession performances. References [7] did an aggregate study of pre and post concession performance of all the Nigerian ports and also found significant improvement in seaport performances in the post concession era. Studies by references [10, 11] also found significant improvement in the productivity of the Calabar seaport in the post-concession era. The implications of the findings of these studies is that port privatization and 
concession have to a fair extent meet some basic objectives that motivated its adoption particularly; improving the performance and productivity of the port terminals. The motivation for this current study, however, is the challenge to sustain the trend of improvement in the post-concession performance of the seaports particularly that of Onne which is our case study. It is only the sustenance of this improvement in post-concession performance of ports that can guarantee sustainable port operations, maritime transport, economic growth and development. This will ensure the intergenerational maintenance of equity levels in productivity of the ports without allowing it to diminish into the poor and declining performance trend of the preconcession era.

To achieve sustainability in the postconcession performance of the seaport, there is a need for informed application of strategic port facility management and port performance planning tools such as port performanceforecastingand benchmarking. Port performance forecasting and benchmarking as productivity planning tools enable deliberate, conscious, strategic and informed programming of pattern and levels of performance expectation and input resources; so that performance (productivity and output) are achieved at programmed set point or within range of set points predetermined as acceptable. This will ensure that productivity is guarded away from unacceptable productivity and performance regions as long as the variables that influence performance are properly monitored to remain at programmed ranges. Thus, the basic principles of performance forecasting and benchmarking as planning tools can be used to ensure the sustainability of the improved post concession performance of the Onne seaport.
1.1. Forecasting and Benchmarking As Tools for Planning the Sustenance of Seaport Performances

Reference [11] notes that forecasting connotes an act of planning which entails futuristic postulations (programming of the future) based on indices of past and present variables. It involves pragmatic decision making that seeks to determine by modeling or programming future targets and expectations based on past and present occurrences. It is therefore true of forecasting that the future exists only in the present [11]. Thus, future performance of seaports with regards to performance variables as cargo throughput, port revenue, ship traffic etc. can be forecasted using appropriate forecasting methods and past and present values of the performance indices so that such future performances can strategically be planned and sustained significantly to remain within the forecasted limits without deviation to unacceptable limits. The forecasts aid port performance planners to determine acceptable performance benchmarks.

Benchmarking as a productivity planning tool is the process of determining a performance benchmark for each performance variable or an aggregate performancebenchmarkfor allperformance variables. A benchmark is looked at as the minimum acceptable performance set point (or range of set points) which forms a reference point or basis for comparison of subsequent performances for the decision on whether subsequent performance levels are acceptable to the organization based on their extent of agreement with the benchmark. Performance benchmarking is, therefore, a strategic performance planning tool employed by organizations to determine performance benchmarks which represent minimum acceptable performance and/ or productivity levels as targets which the organization must strive to achieve with regards to each performance parameter 
for which benchmark was set using her input resources. While it is important that performance benchmarks are met; performances below benchmarks represent poor performances and are unacceptable. Thus, benchmarks reveal deficiencies in performance as current performance levels are compared with already determined levels of performance benchmarks. In so doing, shortcomings which negatively influenced performance to decline below benchmarks can be corrected in order that productivity may improve.

As aforementioned, previous studies indicate improvementin the postconcession performance of Onne seaport terminals starting from the 2006 base year when the seaport terminals were handed over to the private terminal operators. As a result, the appropriate quantified benchmarks can be determined for key performance indicators as port revenue, cargo throughput, ship traffic volume, and etc. starting from the 2006 base year in order that subsequent performances can have quantified common basis for projection and comparison of post concession port performances and subsequent sustenance based on the benchmarks.

\subsection{Objectives of the Study}

The main aim of the study is to appraise the sustainability of the improvement in post concession performance of Onne seaport and determine performance benchmarks for key port performance indicators of cargo throughput, port revenue and ship traffic volume of the seaport as the basis for port productivity projection and assessment. The specific objectives of the study are:

(i) To appraise the sustainability of post concession cargo throughput, port revenue ship traffic statistics, and ship traffic volume performance of Onne seaport.

(ii) To raise performance benchmarks and progression models for sustainability planning and projection of future performance targets for post concession cargo throughput, port revenue ship traffic statistics and ship traffic volume performances of Onne seaport.

(iii) To make recommendations on the basis of research findings.

\subsection{Research Questions}

(i) Was the post concession cargo throughput, port revenue, ship traffic size and ship traffic volume of Onne seaport sustained beyond the respective 2006 base year performance values?

(ii) Can performance benchmarks and progression models be developed for sustainability planning and projection of future cargo throughput, port revenue, ship traffic size and ship traffic volume performances of Onne seaport?

\section{Methodology}

The study employed statistical forecasting and arithmetic progression tools with secondary data to appraise the sustainability of the post concession performance of Onne seaport and determined performance benchmarks for major performance indicators. Ten years (2006 - 2015) time series data was obtained from Nigerian Ports Authority covering performance indicators such as port revenue, cargo throughput and ship traffic volume. It is important to state that the data used for the study was obtained from the Nigerian Ports Authority (NPA) annual statistical bulletin (2015) edition which was made publicly available to the public in both print and online version. Therefore no further authorization is required from the NPA to use the data. The study employed basic mathematical tools of arithmetic differences to unravel deviating in cargo throughput, ship traffic and port revenue performances from the 2006 base year to determine how improvement 
in Onne seaport performances has been sustained at or beyond the level of the base year performance over the period. Thus this enables the researcher to achieve objective 1. Using the symbols $X_{1}, X_{2},--X_{5}$---- $X_{n}$ to represent the post concession performance of the seaport for each performance indicator (parameter) from the base year 2006 to 2015 representing a 10 year period (that is $n=10$ ). A measure of differences between the base year performance values for each parameter and the subsequent year performance is used to determine levels of deviation from base year performance values and sustainability of the improvement in post concession performance of the Onne seaport starting with the base year values for each performance indicator. When $\mathrm{n}=10$ years, the $10^{\text {th }}$ year difference in revenue performance with the base year, for instance, can be measured by the difference operator $X_{n}-X_{1}$; and similarly for the other parameters.

To develop a sequence that models the progression in performance and that forms the basis for sustainability planning and projection of future performance targets and benchmarks for each performance indicator; we note that the performance data for each indicator from 2006 base year to 2015 form a sequence of 10 terms each. Using $C, R$, and $S$ to symbolize cargo throughput, port revenue and ship traffic volume performances respectively; we write the performance sequence for each parameter as:

$C=C_{1}, C_{2}, C_{3}, C_{4}, \cdots-C_{n}$
$R=R_{1}, R_{2}, R_{3}, R_{4}, \cdots--R_{n}$
$S=S_{1}, S_{2}, S_{3}, S_{4}, \cdots-S_{n}$

Where $C_{1}, R_{1}, S_{1}$ = base year ( $1^{\text {st }}$ term) cargo throughput, revenue and ship traffic volume performances of the seaport; $C_{n}, R_{n}$ and $S_{n}=$ $10^{\text {th }}$ term (year) cargo throughput, revenue and ship traffic volume performances of the seaport.
Assuming that the performance sequence progressed by arithmetic progression (AP); such that performance is to be sustained without falling below the $1^{\text {st }}$ term (improved base year performance level) for each indicator by an arithmetic progression. We have:

$U=a, a+d, a+2 d$, $a+n-1(d)$

(i) as the general form of an AP.

Where $U=$ sequence, $a=1^{\text {st }}$ term of the sequence, $d=$ common difference. The difference is however found not to be common for the performance values from the $1^{\text {st }}$ term to the $10^{\text {th }}$ term as shown by the data collected but for purposes of planning, forecasting and projection; a common difference will be found using the sum of the first 10 terms of the sequence as used in this study.

With particular reference to the performance indicators and/or parameters used namely cargo throughput, port revenue and ship traffic volume; we have:

$U_{c}=C_{1}+C_{1}+d+C_{1}+2 d+--\cdot--+C_{1}+(n-1) d$ (ii)

Where $C_{1}=1^{\text {st }}$ term of the sequence $=$ base year (2006) post concession cargo throughput performance level of the port.

$d=$ common difference

$n=$ number of terms $=10$

Similar for revenue we have:

$$
U_{r}=R_{1}+R_{1}+d+R_{1}+2 d+-\cdot-\cdot-+R_{1}+(n-i) d
$$

For ship traffic volume we have:

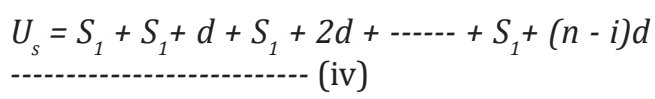


As aforementioned, the difference in performance levels of each parameter for purposes performance projection and sustainability planning using Arithmetic Progression must be common (ie; Common Difference 'd'). To make the difference common for projection and sustainability planning purposes, we recall that the sum of an Arithmetic sequence (AP) is given by:

$S_{n}=n / 2[(2 a+(n-1) d]$

In particular, the sums for cargo throughput, revenue and ship traffic performances will thus be given respectively as:

$S_{c n}=n / 2\left[\left(2 C_{1}+(n-I) d\right]\right.$

$S_{r n}=n / 2\left[\left(2 R_{1}+(n-1) d\right]\right.$

$S_{s n}=n / 2\left[\left(2 S_{1}+(n-1) d\right]\right.$

Thus the common difference for each performance parameter can be determined for purposes of projecting and port performance sustainability planning using equations (vi), (vii) and (viii) and making $\mathrm{d}$ the subject of the equations.

Having obtained the common differences for each performance indicator, the $\mathrm{n}^{\text {th }}$ term for each performance parameter can be projected using the formula:

$n^{\text {th }}$ term $=C_{1}+(n-1) d$

(ix); for cargo throughout performance

$n^{\text {th }}$ term $=R_{1}+(n-1) d$

$(x)$; for revenue performance

$n^{\text {th }}$ term $=S_{1}+(n-1) d$

(xi); for ship traffic volume
Using the above equations can project and model the basis for progression and sustenance of Onne seaport post concession performance which objective 2 sort to achieve.

To development benchmark as target and basis for port performance assessment; we recall that benchmarks are best developed using AP at points from where or which the sequence diverges farther and farther away to positive infinity provided such points are at acceptable performance levels. From infinity, sequence equally converges (comes closer and closer) to the benchmark term (ie fixed point). See figure 1 below.

Figure 1. Divergence and Convergence of Post Concession Performances from and to Performance Benchmarks

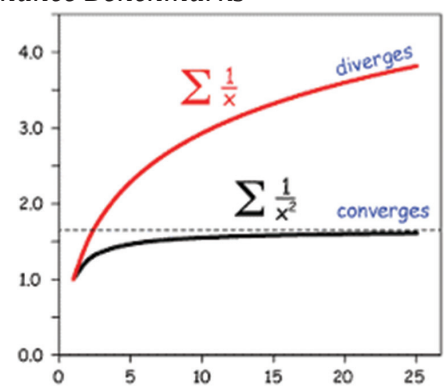

Source: www.xakly.com/images/pseries

The $1^{\text {st }}$ term (2006 base year) performance of the seaport in each performance parameter reveal higher/ improved post concession performance than the pre concession years and since this year marks the $1^{\text {st }}$ year of the post concession era which recorded improved performance of the port productivity indicators, we assume that the 2006 base year $\left(1^{\text {st }}\right.$ term $)$ performance levels is within acceptable performance region/level; thus the AP builds a benchmark around it such that $\mathrm{n}^{\text {th }}$ term for each parameter;

$n^{\text {th }}$ term $=C_{1}+(n-1) d$; for cargo through.

$n^{\text {th }}$ term $=R_{1}=(n-1) d$; for Port revenue. 
$n^{\text {th }}$ term $=S_{1}=(n-1) d$; for ship traffic volume.

Thus benchmarks are developed at $C_{1}, R_{1}$, and $S_{1}$ levels of performances. Sustainability planning is thus based on these and subsequent performances compared with these benchmarks such that subsequent performances are proactively caused to diverge from the benchmark levels/values to positive infinity and in adverse economic conditions; performances are monitored to converge on the benchmarks ( $1^{\text {st }}$ terms $)$ and not allowed to fall below it. Performances below these benchmarks are indications of relapsing of performances into the poor performance regions of the pre concession era. This is unacceptable because it does not meet the performance objectives of privatization and concession. Performance comparisons in subsequent years can then be made based on the benchmarks.

Also subtracting the base year (2006) performance value of each parameter from the subsequent years' performance enables us to determine if performance was progressively sustained beyond, at or retrogressively below the base year performance values.

Using 'MATLAB' software and adopting the methods discussed above, the study was carried out in other to achieve the research objectives.

\section{Limitation of the Study}

The data used for the study was sourced from the NPA annual statistical bulletin covering the period from 2006 to 2015 . As a result, the accuracy of the results and findings to a large extent will be dependent of the accuracy of the data used.

\section{Results and Findings}

The result of the analysis indicates that the subsequent ship traffic performance of the port for the periods (years) after 2006 base year was not consistently sustained at or progressively beyond that of the 2006 base year performance value of 443. Ship traffic performance of the port was only progressively sustained beyond the 2006 base year value (increased) in 2010, 2011, and 2013 by 29, 22 and 1 respectively. The years 2007, 2008, 2009, 2012, 2014 and 2015 which shows

Table 3. Sustainability Appraisal of Post Concession Ship Traffic Performance of Onne Port (2006 -2015)

\begin{tabular}{|c|c|c|c|}
\hline S/no. & Year & Vessel traffic stat & $\mathbf{N}^{\text {th }}$ term $\mathbf{a}$ \\
\hline 1 & 2006 & 443 & - \\
\hline 2 & 2007 & 407 & -36 \\
\hline 3 & 2008 & 348 & -95 \\
\hline 4 & 2009 & 435 & -8 \\
\hline 5 & 2010 & 414 & 29 \\
\hline 6 & 2011 & 465 & 22 \\
\hline 7 & 2012 & 435 & -8 \\
\hline 8 & 2013 & 444 & 1 \\
\hline 9 & 2014 & 438 & -5 \\
\hline 10 & 2015 & 415 & -28 \\
\hline Sum & & 4,244 & \\
\hline
\end{tabular}

Source: Authors Computation based on Data Collected 
Table 4. Determining the Common Differenced based on $S_{n}$ and a for Ship Traffic Performance Sustainability Planning based on -----(1)

\begin{tabular}{|c|c|c|}
\hline $\mathbf{S}_{\mathbf{n}}=\mathbf{n} / \mathbf{2}(\mathbf{2 a}+\mathbf{( n - 1 ) d}$ & $\mathbf{a}=\mathbf{V}_{\mathbf{1}}$ & $\mathbf{d}$ \\
\hline 4244 & 443 & -21 \\
\hline
\end{tabular}

Source: Authors Calculation

negative $\mathrm{N}^{\text {th }}$ term - a values witnessed lower ship traffic performance than the base year; an indication that the high ship traffic performance of the port in 2006 post concession base year could not be surpassed and/ or sustained in those. Since ship traffic performance of the port is a measure of the aggregate sum of vessels that called or berthed at the port over the period, it is an important factor which influences port revenue generation and cargo (customs) charges since both revenue and cargo charges are dependent variables on ship traffic of the port. The implication is that, decreasing trend of ship traffic performance as witnessed in the post concession performances of Onne port may at the long run induce revenue and cargo charges among other variables dependent on it to take decreasing trend. Planning is therefore needed to ensure that ship traffic performance of the port is progressively sustained to achieve values beyond or at the base year value as benchmark to curb performance from relapsing into the poor performance trend of the pre concession era. The studies of references [6] and [7] also found similar inconsistently declining trend in the post concession ship traffic performances of the Nigerian seaports.

The tables indicate that the aggregate sum of 4244 vessels called at the port over the period, for sustainability planning a common difference 'd' -21 vessels. For sustainability planning, we assume a positive common difference since a negative common difference indicate a decreasing performance trend against a desired positively increasing/progressive performance trend which is always the target of sustainability planning. Using the common difference of 21 , the post concession vessel traffic performance of Onne port is projected/extrapolated and panned for performance sustainability for the next 10 years starting with 2016 as shown in the table below.

Table 5. 10 Years Progression Model for Benchmarking and Sustainability Planning/Projection of Post Concession Ship Traffic Performance of Onne Port (2016 -2025)

\begin{tabular}{|c|c|c|c|c|}
\hline $\mathbf{S} / \mathbf{n}$ & Year & No. of Term & $\begin{array}{c}\text { Progression and Sustainability Planning } \\
\text { Model }\end{array}$ & $\begin{array}{c}\text { Projected Forecast } \\
\text { Value }\end{array}$ \\
\hline 1 & 2016 & $11^{\text {th }}$ term & $\mathrm{V}_{1}+(\mathrm{n}-1) \mathrm{d}=\mathrm{V}_{1}+10 \mathrm{~d}$ & 653 \\
\hline 2 & 2017 & $12^{\text {th }}$ term & $\mathrm{V}_{1}+(\mathrm{n}-1) \mathrm{d}=\mathrm{V}_{1}+11 \mathrm{~d}$ & 674 \\
\hline 3 & 2018 & $13^{\text {th }}$ term & $\mathrm{V}_{1}+(\mathrm{n}-1) \mathrm{d}=\mathrm{V}_{1}+12 \mathrm{~d}$ & 695 \\
\hline 4 & 2019 & $14^{\text {th }}$ term & $\mathrm{V}_{1}+(\mathrm{n}-1) \mathrm{d}=\mathrm{V}_{1}+13 \mathrm{~d}$ & 716 \\
\hline 5 & 2020 & $15^{\text {th }}$ term & $\mathrm{V}_{1}+(\mathrm{n}-1) \mathrm{d}=\mathrm{V}_{1}+14 \mathrm{~d}$ & 737 \\
\hline 6 & 2021 & $16^{\text {th }}$ term & $\mathrm{V}_{1}+(\mathrm{n}-1) \mathrm{d}=\mathrm{V}_{1}+15 \mathrm{~d}$ & 758 \\
\hline 7 & 2022 & $17^{\text {th }}$ term & $\mathrm{V}_{1}+(\mathrm{n}-1) \mathrm{d}=\mathrm{V}_{1}+16 \mathrm{~d}$ & 779 \\
\hline 8 & 2023 & $18^{\text {th }}$ term & $\mathrm{V}_{1}+(\mathrm{n}-1) \mathrm{d}=\mathrm{V}_{1}+17 \mathrm{~d}$ & 800 \\
\hline 9 & 2024 & $19^{\text {th }}$ term & $\mathrm{V}_{1}+(\mathrm{n}-1) \mathrm{d}=\mathrm{V}_{1}+18 \mathrm{~d}$ & 821 \\
\hline 10 & 2025 & $20^{\text {th }}$ term & $\mathrm{V}_{1}+(\mathrm{n}-1) \mathrm{d}=\mathrm{V}_{1}+19 \mathrm{~d}$ & 842 \\
\hline
\end{tabular}

Source: Author's Calculation 
The table shows the progression models determined based on the result of the analysis for sustainability planning to ensure that ship traffic performance of the seaport does not fall below the performance target. Thus the port authority and terminal operators should, for example, target to achieve a ship traffic performance of 842 vessels in the year 2025, following the previous performance sequence. Thus, ship traffic performance figure below 842 in the year 2025 is an indication that the performance target was not met. Comparison with performance benchmark will thus indicate if post concession performance was sustained at, above or below benchmark value. From the result on Table 4, the post concession performance benchmark for ship traffic statistics of Onne port is $\mathrm{a}=\mathrm{V}_{1}=443$ vessels. From this improved post concession ship traffic performance value/point, performances can progressive diverge to infinity or converge to benchmark. Performance below 443 vessels is indicative of diminishing performance into poor performance trend of the pre concession era. Thus, for the continuous progression of post concession ship traffic performance of Onne port, $V_{1}$ $+(n-1) d \geq V_{1}$. ie; $V_{1}+(n-1) d \geq 443$ is a condition that must be met.

Table 6 below shows the post concession ship traffic volume of Onne port. Since ship traffic volume measured in Gross registered tonnage (GRT) is a measure of the total internal space (both cargo space and engine/ lightship space) that entered the port over a time period, it influences port revenue generation and cargo charges since ports tend to have higher charges for bigger size vessels. The $\mathrm{N}^{\text {th }}$ term - a values of post concession ship traffic volume performance in each subsequent year after the 2006 base year value is positive. This indicates that subsequent post concession ship traffic volume performance of the port is greater in each year than in the based. We thus infer that the port has consistently and progressively sustained its post concession ship traffic volume beyond/above the base year value. The implication is that even when the trend of vessel calls at the port is decreasing as indicated in Table 5, ship traffic volume is increasing and thus cargo throughput may increase since vessels with bigger cargo carrying capacity called

Table 6. Sustainability Appraisal of Post Concession Ship Traffic Volume Performance of Onne Port (2006-2015)

\begin{tabular}{|c|c|c|c|}
\hline S/no. & Year & Vessel volume & $\mathbf{N}^{\text {th }}$ term - a \\
\hline 1 & 2006 & $25,683,104$ & - \\
\hline 2 & 2007 & $34,302,177$ & $8,619,073$ \\
\hline 3 & 2008 & $27,901,126$ & $2,218,022$ \\
\hline 4 & 2009 & $27,171,664$ & 1488560 \\
\hline 5 & 2010 & $37,423,926$ & 117440822 \\
\hline 6 & 2011 & $42,735,452$ & 17052340 \\
\hline 7 & 2012 & $42,062,351$ & 16379247 \\
\hline 8 & 2013 & $38,967,131$ & 13284027 \\
\hline 9 & 2014 & $26,879,605$ & 1196501 \\
\hline 10 & 2015 & $26,572,745$ & 889641 \\
\hline Sum & & $276,246,931$ & \\
\hline
\end{tabular}

Source: Authors Computation based on Data Collected 
at the port in subsequent years than in 2006. Port authorities thus may take into consideration dredging to deepen already existing berth or building deeper berth and increasing draught levels in order to attract higher capacity vessel to maintain and or sustain the post concession ship traffic volume performance of the port.
The table indicates the post concession ship traffic volume performance progression and sustainability planning models developed for Onne port for each year from 2016 to 2025. For example, the ship traffic volume performance of Onne port in 2025 which marks the $20^{\text {th }}$ year (2 decades) of privatization of Onne port

Table 7. Sustainability Planning of Onne Ship Traffic Volume Performance Using a Common Difference

\begin{tabular}{|c|c|c|}
\hline $\mathbf{S}_{\mathbf{n}}=\mathbf{n} / \mathbf{2}\left(\mathbf{2} \mathbf{S}_{\mathbf{1}}+\mathbf{( n - 1 ) \mathbf { ~ }}\right.$ & $\mathbf{a}=\mathbf{S}_{\mathbf{1}}$ & $\mathbf{d}$ \\
\hline $276,246,931$ & $256,831,040$ & $431,464.24$ \\
\hline
\end{tabular}

Source: Authors Calculation

The result of the analysis determined the sum $\mathrm{S}_{\mathrm{n}}$ of ship traffic volume performance of the port as 276,246,931 upon which a common difference of $431,464.24$ was determined for sustainability planning and projection of the targeted post concession ship traffic volume performance of the seaport. Based on ' $d$ ' and the first term, a 10 years post concession ship traffic volume sustainable performance plan was developed for Onne as shown in the table below starting from 2016. based on the post concession performance sequence is forecasted to progress to 284444749 Net Registered Tonnage (NRT). The post concession ship traffic volume performance benchmark from which performance can diverge to infinity is at a $=\mathrm{S}_{1}=256,831,040$ NRT. Thus the condition that ensures the sustenance of the post concession ship traffic volume performance of Onne port is: $\mathrm{S}_{1}+(\mathrm{n}-1) \mathrm{d} \geq \mathrm{S}_{1}=\mathrm{S}_{1}+(\mathrm{n}-1) \mathrm{d}$ $\geq 256,831,040$ NetRegistered Tonnage. This same condition ensures that performance

Table 8. 10 years Progression Model for Benchmarking and Sustainability Planning/Projection of Post Concession Ship Traffic Volume Performance of Onne Port (2016 -2025)

\begin{tabular}{|c|c|c|c|c|}
\hline $\mathbf{S} / \mathbf{n}$ & Year & No. of Terms & $\begin{array}{c}\text { Progression and Sustainability } \\
\text { Planning Model }\end{array}$ & $\begin{array}{c}\text { Projected Forecast } \\
\text { Value (NRT) }\end{array}$ \\
\hline 1 & 2016 & $11^{\text {th }}$ term & $\mathrm{S}_{1}+(\mathrm{n}-1) \mathrm{d}=\mathrm{S}_{1}+10 \mathrm{~d}$ & 280561573 \\
\hline 2 & 2017 & $12^{\text {th }}$ term & $\mathrm{S}_{1}+(\mathrm{n}-1) \mathrm{d}=\mathrm{S}_{1}+11 \mathrm{~d}$ & 280993037 \\
\hline 3 & 2018 & $13^{\text {th }}$ term & $\mathrm{S}_{1}+(\mathrm{n}-1) \mathrm{d}=\mathrm{S}_{1}+12 \mathrm{~d}$ & 281424501 \\
\hline 4 & 2019 & $14^{\text {th }}$ term & $\mathrm{S}_{1}+(\mathrm{n}-1) \mathrm{d}=\mathrm{S}_{1}+13 \mathrm{~d}$ & 281855965 \\
\hline 5 & 2020 & $15^{\text {th }}$ term & $\mathrm{S}_{1}+(\mathrm{n}-1) \mathrm{d}=\mathrm{S}_{1}+14 \mathrm{~d}$ & 282287429 \\
\hline 6 & 2021 & $16^{\text {th }}$ term & $\mathrm{S}_{1}+(\mathrm{n}-1) \mathrm{d}=\mathrm{S}_{1}+15 \mathrm{~d}$ & 282718893 \\
\hline 7 & 2022 & $17^{\text {th }}$ term & $\mathrm{S}_{1}+(\mathrm{n}-1) \mathrm{d}=\mathrm{S}_{1}+16 \mathrm{~d}$ & 283150357 \\
\hline 8 & 2023 & $18^{\text {th }}$ term & $\mathrm{S}_{1}+(\mathrm{n}-1) \mathrm{d}=\mathrm{S}_{1}+17 \mathrm{~d}$ & 283581821 \\
\hline 9 & 2024 & $19^{\text {th }}$ term & $\mathrm{S}_{1}+(\mathrm{n}-1) \mathrm{d}=\mathrm{S}_{1}+18 \mathrm{~d}$ & 284013285 \\
\hline 10 & 2025 & $20^{\text {th }}$ term & $\mathrm{S}_{1}+(\mathrm{n}-1) \mathrm{d}=\mathrm{S}_{1}+19 \mathrm{~d}$ & 284444749 \\
\hline
\end{tabular}

Source: Authors Calculation 
Table 9. Sustainability Appraisal of Post Concession Revenue Performance of Onne Port (2006 -2015)

\begin{tabular}{|c|c|c|c|}
\hline S/no. & Year & $\begin{array}{c}\text { Revenue Generated } \\
\text { Million(USD) }\end{array}$ & $\mathbf{N}^{\text {th }}$ term - a \\
\hline 1 & 2006 & 103.76 & - \\
\hline 2 & 2007 & 128.24 & 24.48 \\
\hline 3 & 2008 & 139.27 & 35.51 \\
\hline 4 & 2009 & 117.96 & 14.2 \\
\hline 5 & 2010 & 150.34 & 46.58 \\
\hline 6 & 2011 & 255.56 & 151.8 \\
\hline 7 & 2012 & 245.84 & 142.08 \\
\hline 8 & 2013 & 251.43 & 147.67 \\
\hline 9 & 2014 & 267.58 & 163.67 \\
\hline 10 & 2015 & 243.22 & 139.46 \\
\hline Sum & & 1659.46 & \\
\hline
\end{tabular}

Source: Authors computation based on data collected

progressively diverges to infinity from $S_{1}$ in performance of the port in the subsequent normal time and converges at $s_{1}$ in time of years (terms) after 2006 in the post economic recession affecting the port. concession era was far beyond the based

The result of the analysis shown in year (2006) value of $R_{1}=103.76$ million Table 9 above indicates that the revenue USD. Thus the revenue performance of the Table 10. Sustainability Planning of Onne Port Post Concession Revenue Performance Using a Common Difference

\begin{tabular}{|c|c|c|}
\hline $\mathbf{S}_{\mathbf{n}}=\mathbf{n} / \mathbf{2}\left(\mathbf{2} \mathbf{R}_{\mathbf{1}}+\mathbf{( n - 1 ) \mathbf { d }}\right.$ & $\mathbf{a}=\mathbf{R}_{\mathbf{1}}$ & $\mathbf{d}$ \\
\hline 1659.46 & 103.76 & 13.82 \\
\hline
\end{tabular}

Source: Authors Computation

Table 11. 10 years Progression Model for Benchmarking and Sustainability Planning/Projection of Post Concession Revenue Performance of Onne Port (2016 -2025)

\begin{tabular}{|c|c|c|c|c|}
\hline S/n & Year & No. of Term & Projection/Planning Model & $\begin{array}{c}\text { Planned Sustainability /Projected } \\
\text { Forecast Value in Million USD }\end{array}$ \\
\hline 1 & 2016 & $11^{\text {th }}$ term & $\mathrm{R}_{1}+(\mathrm{n}-1) \mathrm{d}=\mathrm{R}_{1}+10 \mathrm{~d}$ & 241.96 \\
\hline 2 & 2017 & $12^{\text {th }}$ term & $\mathrm{R}_{1}+(\mathrm{n}-1) \mathrm{d}=\mathrm{R}_{1}+11 \mathrm{~d}$ & 255.78 \\
\hline 3 & 2018 & $13^{\text {th }}$ term & $\mathrm{R}_{1}+(\mathrm{n}-1) \mathrm{d}=\mathrm{R}_{1}+12 \mathrm{~d}$ & 269.6 \\
\hline 4 & 2019 & $14^{\text {th }}$ term & $\mathrm{R}_{1}+(\mathrm{n}-1) \mathrm{d}=\mathrm{R}_{1}+13 \mathrm{~d}$ & 283.42 \\
\hline 5 & 2020 & $15^{\text {th }}$ term & $\mathrm{R}_{1}+(\mathrm{n}-1) \mathrm{d}=\mathrm{R}_{1}+14 \mathrm{~d}$ & 311.06 \\
\hline 6 & 2021 & $16^{\text {th }}$ term & $\mathrm{R}_{1}+(\mathrm{n}-1) \mathrm{d}=\mathrm{R}_{1}+15 \mathrm{~d}$ & 324.88 \\
\hline 7 & 2022 & $17^{\text {th }}$ term & $\mathrm{R}_{1}+(\mathrm{n}-1) \mathrm{d}=\mathrm{R}_{1}+16 \mathrm{~d}$ & 338.7 \\
\hline 8 & 2023 & $18^{\text {th }}$ term & $\mathrm{R}_{1}+(\mathrm{n}-1) \mathrm{d}=\mathrm{R}_{1}+17 \mathrm{~d}$ & 352.52 \\
\hline 9 & 2024 & $19^{\text {th }}$ term & $\mathrm{R}_{1}+(\mathrm{n}-1) \mathrm{d}=\mathrm{R}_{1}+18 \mathrm{~d}$ & 366.34 \\
\hline 10 & 2025 & $20^{\text {th }}$ term & $\mathrm{R}_{1}+(\mathrm{n}-1) \mathrm{d}=\mathrm{R}_{1}+19 \mathrm{~d}$ & \\
\hline
\end{tabular}

Source: Author's Calculation 
port in each year between 2006 and 2015 was progressively sustained above the base year improved performance value. This is an indication of fair and sustained revenue performance. This supports the findings of references [7] and [10] who found improvements in the post concession revenue performances of Nigerian seaports.

The result shows that the sum total of 1659460000 USD was generated as the aggregate post concession revenue performance of the port by the Nigerian ports Authority NPA over the 10 years period covered in the study, starting with a post concession base year revenue performance of 103.76 in 2006. Based on this, the post concession revenue performance sequence, a common difference 'd' of 13.82 USD was determined for purposes of developing a progression model for sustainability planning of port revenue.

Table 11 above indicates the post concession revenue performance progression and sustainability planning models developed for Onne port for each year from 2016 to 2025. For example, the revenue performance of Onne port in 2025, which marks the $20^{\text {th }}$ year $(2$ decades) of privatization of Onne port based on the post concession performance sequence, is forecasted to progress to 366.34 MillionUSD. The post concession revenue performance benchmark from which performance can diverge to infinity is at $\mathrm{a}=\mathrm{R}_{1}=103.76$ MillionUSD. Thus the condition that ensures the sustenance of the post concession revenue performance of Onne port is: $R_{1}+(n-1) d \geq R_{1}=R_{1}+$ ( $\mathrm{n}-1$ ) d $\geq 103.76$ MillionUSD. This same condition ensures that performance progressively diverges to infinity from $R_{1}$ all things being equal; and converges at $R_{1}$ in time of economic recession affecting the port. Below $\mathrm{R}_{1}$ is an indication that revenue performance is relapsing into the poor performance trend of the pre concession/ privatization era.

In 2007, the port failed to sustain her post concession cargo throughput performance above or at the 2006 post concession base year value. The $\mathrm{N}^{\text {th }}$ Terms - a values for the other years between 2008 and 2015 show positive values greater than zero; this indicates that the post concession

Table 12. Sustainability Appraisal of Post Concession Cargo Throughput Performance of Onne Port (2006-2015)

\begin{tabular}{|c|c|c|c|}
\hline S/no. & Year & Cargo Throughput (MT) & $\mathbf{N}^{\text {th }}$ term - a \\
\hline 1 & 2006 & $2,554,759$ & - \\
\hline 2 & 2007 & $2,482,177$ & -72582 \\
\hline 3 & 2008 & $3,222,663$ & 667904 \\
\hline 4 & 2009 & $3,385,455$ & 830,696 \\
\hline 5 & 2010 & $2,921,727$ & 366,968 \\
\hline 6 & 2011 & $3,309,815$ & 755,056 \\
\hline 7 & 2012 & $3,877,024$ & $1,322,265$ \\
\hline 8 & 2013 & $3,872,495$ & $1,317,736$ \\
\hline 9 & 2014 & $4,556,390$ & $2,001,631$ \\
\hline 10 & 2015 & $4,621,110$ & $2,066,351$ \\
\hline Sum & & $34,803,615$ & \\
\hline
\end{tabular}

Source: Authors Computation based on Data Collected from NPA Onne 
cargo throughput performance of the seaport in the subsequent years between 2008 and 2015 were sustained above that of the base year. This is in agreement with the findings of references [6] and [11]. the table above starting from the year 2016 .

The table indicates the post concession revenue performance progression and sustainability planning models developed for Onne port for each year from 2016 to

Table 13. Sustainability Planning of Post Concession Cargo Throughput Performance of Onne Port Using a Common Difference Operator

\begin{tabular}{|c|c|c|}
\hline $\mathbf{S}_{\mathbf{n}}=\mathbf{n} / \mathbf{2}\left(\mathbf{2} \mathbf{C}_{\mathbf{1}}+(\mathbf{n}-\mathbf{1}) \mathbf{d}\right.$ & $\mathbf{A}=\mathbf{C}_{\mathbf{1}}$ & $\mathbf{D}$ \\
\hline $34,803,615$ & $2,554,795$ & 205689.44 \\
\hline
\end{tabular}

Source: Author's Calculation

The Table 13 above indicates that the sum total cargo throughput over the period covered in the study is $34,803,615$ based on which a common difference 'd' of 205689.44 was determined. Based on the common difference and the first term ' $a$ ' $=2554795$, sustainability plan can be projected for the post concession cargo throughput performance of Onne. Performance benchmark can equally be determined. The table below shows the post concession cargo throughput performance sustainability plan based on the first term ' $a$ ' and common difference ' $d$ ' as shown in
2025. For example, the cargo throughput performance of Onne port in 2025, which marks the $20^{\text {th }}$ year ( 2 decades) of privatization of Onne port based on the post concession performance sequence, is forecasted to progress to 6,462,894 metric tons. The post concession cargo throughput performance benchmark from which performance can diverge to infinity is at $\mathrm{a}=\mathrm{C}_{1}=2,554,795$ metric tons.. Thus the condition that ensures the sustenance of the post concession cargo throughput performance of Onne port is: $C_{1}+(n-1) d \geq$ $\mathrm{C}_{1}$. Ie; $\mathrm{C}_{1}+(\mathrm{n}-1) \mathrm{d} \geq 2,554,795$ metric tons.

Table 14. 10 years Progression Model for Benchmarking and Sustainability Planning/Projection of Post Concession Cargo Throughput Performance of Onne Port (2016 -2025)

\begin{tabular}{|c|c|c|c|c|}
\hline $\mathbf{S} / \mathbf{n}$ & Year & No. of Terms & $\begin{array}{c}\text { Progression and Sustainability } \\
\text { Planning Model }\end{array}$ & $\begin{array}{c}\text { Projected Forecast } \\
\text { Value (MT) }\end{array}$ \\
\hline 1 & 2016 & $11^{\text {th }}$ term & $\mathrm{C}_{1}+(\mathrm{n}-1) \mathrm{d}=\mathrm{C}_{1}+10 \mathrm{~d}$ & 4611689.4 \\
\hline 2 & 2017 & $12^{\text {th }}$ term & $\mathrm{C}_{1}+(\mathrm{n}-1) \mathrm{d}=\mathrm{C}_{1}+11 \mathrm{~d}$ & 4817378.8 \\
\hline 3 & 2018 & $13^{\text {th }}$ term & $\mathrm{C}_{1}+(\mathrm{n}-1) \mathrm{d}=\mathrm{C}_{1}+12 \mathrm{~d}$ & 5023068.2 \\
\hline 4 & 2019 & $14^{\text {th }}$ term & $\mathrm{C}_{1}+(\mathrm{n}-1) \mathrm{d}=\mathrm{C}_{1}+13 \mathrm{~d}$ & 5228757.6 \\
\hline 5 & 2020 & $15^{\text {th }}$ term & $\mathrm{C}_{1}+(\mathrm{n}-1) \mathrm{d}=\mathrm{C}_{1}+14 \mathrm{~d}$ & 5434447 \\
\hline 6 & 2021 & $16^{\text {th }}$ term & $\mathrm{C}_{1}+(\mathrm{n}-1) \mathrm{d}=\mathrm{C}_{1}+15 \mathrm{~d}$ & 5640136.4 \\
\hline 7 & 2022 & $17^{\text {th }}$ term & $\mathrm{C}_{1}+(\mathrm{n}-1) \mathrm{d}=\mathrm{C}_{1}+16 \mathrm{~d}$ & 5845825.8 \\
\hline 8 & 2023 & $18^{\text {th }}$ term & $\mathrm{C}_{1}+(\mathrm{n}-1) \mathrm{d}=\mathrm{C}_{1}+17 \mathrm{~d}$ & 6051515.2 \\
\hline 9 & 2024 & $19^{\text {th }}$ term & $\mathrm{C}_{1}+(\mathrm{n}-1) \mathrm{d}=\mathrm{C}_{1}+18 \mathrm{~d}$ & 6257204.6 \\
\hline 10 & 2025 & $20^{\text {th }}$ term & $\mathrm{C}_{1}+(\mathrm{n}-1) \mathrm{d}=\mathrm{C}_{1}+19 \mathrm{~d}$ & 6462894 \\
\hline
\end{tabular}

Source: Author's Calculation 


\section{Managerial Implications}

It is in the interest of port managers and terminal operators to maintain acceptable levels of productivity as well as ensuring that this high level of productivity, once achieved, is sustained continually. The implication is that quantitative models must be determined and proactively used to grow and sustain seaport performances. The study therefore has produced empirical guides for performance benchmarking and performance targets for port performance variables of vessel traffic, ship traffic volume, cargo throughput, and port revenue which port managers and terminal operators may adopt in projecting, comparing, and sustaining seaport and terminal performances. The benefits are that port managers and terminal operators may thus proactively improve and sustain the post concession port revenue, ship traffic volume, vessel traffic size, and cargo throughput of the seaports without giving room for its decline below benchmarks in the poor productivity regions of pre concession era. This will consequently improve and sustain the overall productivity of the maritime transport system.

\section{Conclusion}

It is evident from the result that while the post concession cargo throughput, port revenue, and ship traffic volume performance of the Onne seaport showed sustained progression from the 2006 base year values, the ship traffic statistics of the port illustrating the number of vessels that called at the port per annum shows an overall decline from the base year value, indicating that the port was unable to progressively sustain her ship traffic performance within the period. The post concession performance benchmark for each performance parameter of cargo throughput, port revenue, ship traffic volume, and ship traffic statistics are $\mathrm{C}_{1}=2,554,795$ metric tons, $\mathrm{R}_{1}=103.76$
MillionUSD, $\mathrm{S}_{1}=256,831,040 \mathrm{NRT}$, and $\mathrm{V}_{1}$ $=443$ vessels respectively. The conditions for sustenance of the post concession cargo throughput, port revenue, ship traffic volume, and ship traffic statistics performance of the port are: $\mathrm{C}_{1}+(\mathrm{n}-1)$ $\mathrm{d} \geq 2,554,795$ metric tonnes, $\mathrm{R}_{1}+(\mathrm{n}-1)$ $\mathrm{d} \geq 103.76$ MillionUSD, $\mathrm{S}_{1}+(\mathrm{n}-1) \mathrm{d} \geq$ 256,831,040 Net Registered Tonnage and $V_{1}+(n-1) d \geq 443$ respectively.

\section{Recommendation}

The performance sequence of the port should be the basis for planning the sustenance of port productivity. As a result, it is recommended that the performance benchmarks and sustainable productivity conditions determined for port performance indicators of cargo throughput, port revenue, ship traffic volume and ship traffic statistics based on post concession performance sequence of the port, should be the basis for sustainability planning and benchmarking of the post concession performance of Onne seaport.

\section{Suggestions for Further Studies}

Further studies should be carried out to determine benchmarks for sustainability planning and productivity improvement in other major seaports in Nigeria. A comparison of performance benchmarks determined for all the major seaports in Nigerian should equally be carried to develop empirical guide for port managers and terminal operators in their drive for performance improvement and sustenance. The actual post concession performances of the seaports from 2016 to 2025 with respect to the various performance indicators will be compared after 2025 with the forecasted/projected performances and benchmarks to determine if significant differences exist. 


\section{References}

[1] Tatyana, P. S. (2004) Beyond economic growth: An introduction to sustainable development. International Bank for Reconciliation (World Bank), Washington.

[2] Ndikom O.B., (2006) Kernel concept of shipping operations, policies and strategies: the industry overview. Bunmico publishers, Lagos.

[3] World Bank and PPIAF (2007) "How the Haskoning Study Shaped Nigerian Port Reform." Draft report. Washington, DC. Washington, DC.

[4] Mohiuddin, Arif. Royal Haskoning (2002) "Technical and Financial Assessment of the Nigerian Port Sector: Recommendations for Port Reform." Report to the Nigerian Federal Ministry of Transport.

[5] James Leigland and Gylfi Palsson (2007) port reform in Nigeria Upstream policy reforms kick-start one of the world's largest concession programs. Gridelines publication.

[6] Okeudo G.N. (2013) Effect of Port Reform on Cargo Throughput Level at Onne Seaport Nigeria. A Comparative Study Before and After Reform Policy Implementation. IOSR Journal of Business and Management, Volume 12, (1) PP 71-78.

[7] Olaogbebikan Jimoh Eniola* Ikpechukwu Njoku Faniran Akin Oluwatosin and Enosko Okoko(2014) Performance Evaluation of Nigerian Ports: Pre and Post Concession Eras. Civil and Environmental Research Vol.6.(2).

[8] Victor O, Ikechukwu A., Obioma R, Callistus C., and David A. (2015): Infrastructure Financing and Management: The Impact of Concession on the Operations and Performance of Nigerian Seaports. Journal of Behavioural Economics, Finance,
Accounting and Transport, 2015, Vol. 3, No. 2, 65-70.

[9] Nwokedi T.C., Emeghara G.C., Ikeogu C. (2015) Trend Analysis Of Impacts Of Cargo Pilferage Risk On Post Concession Cargo Throughput Performance of Nigerian Seaport Terminals. International Journal of Research Commercial and Management. Vol. 5 (7) 11- 15.

[10] Bassey j. Bassey \& David d. Emi (2014) the impact of Concessioning on Performance of Calabar Seaport. Multidisplinary Jouraial of Research on Developmental Perspectives. Vol. $3(1)$.

[11] Ndikom, O.B, (2006), The Essentials of Port Reforms: The Nigerian Experience. Lagos: Bunmico Publishers, Lagos. 